\title{
From Zi Wei (滋味) to Qi Yun (气韵), and Yi Jing (意境): Rethinking of Chinese Traditional Artistic Category System
}

\author{
YI Cun-guo \\ Shanghai Jiao Tong University, Shanghai, China
}

\begin{abstract}
The Chinese traditional aesthetic culture not only pay attention to the overall sense of He Xie (Harmony, 和谐), and pay attention to a kind of artistic conception as Zi Wei (滋味), Qi Yun (气韵), and Yi Jing (意境) as well. Mr. JI Xian-lin had tried to start from Zi Wei (滋味), a new comprehension to open a new understanding on Chinese aesthetics. Hence, we embark from the Chinese aesthetic culture and its basic spirit, the humanistic connotation of Zi Wei (滋味), which sounds with the basis, put forward it into a Music-Dance Spirit (“乐舞精神”) in Chinese art through this unique view, has made a new thinking to the Chinese traditional aesthetic artistic category system.
\end{abstract}

Keywords: aesthetic culture, He Xie (Harmony, 和谐), Zi Wei (滋味), Qi Yun (气韵), Yi Jing (意境), Music-Dance Spirit (“乐舞精神”)

\section{Introduction}

The Chinese culture has a long history, with profound knowledge and connotation. "Music" is not only the foundation of the Chinese civilization, but also the main cultural spirit penetrating through it for thousands of years. In general, the Chinese traditional culture is an aesthetic culture, and in this system, art is the core, and music as formed the "spirit", which well versed in all types of art in Chinese arts. Thus, "Qin, Chess, Calligraphy, and Painting" is not only for the "love of Life" spirit which lay the base of the Chinese nation, is also the status quo of the Chinese traditional culture by the sense of Zi Wei (滋味), to the culture of Pin Wei (品味), by the pursuit of Dan Wei (淡味), and gradually transition to the conscious pursuit of Qi Yun (气韵), Yi Jing (意境), and He Xie (Harmony, 和谐), which gradually integrates the cultural aesthetic traditions of Chinese arts constituted a clear cultural understanding the aesthetic category series of system, undoubtedly, Zi Wei (滋味) in which plays an important role in primary.

\section{New Inquiry on “Sheep Big, Beauty Great” (“羊大为美”)}

Chinese nation as well as other nations in the world, in the early days also experienced a totem worship and witchcraft etiquette in this stage, and gathered together under the banner "Dragon Flying, Phoenix Dancing” (龙 飞凤舞) clan group which is a blend of different “tribal totem”, in which being a "sheep” totem. Because totem is often with local closely related to human production and and rational life, and the "sheep" in the early days also

YI Cun-guo, Ph.D., professor, the Institute of Advanced Study on European Culture, Shanghai Jiao Tong University. 
occupies an important position in people’s economic life, so "sheep" also occupies an important place in Chinese culture.

According to the explanation of On Words (《说文解字》), Qiang (美) stands for Xi Rong (西戎), a tribe of the shepherd.

It is worth noting that the rate of "westward" movement in the early Chinese culture plays a great role, there even being a sound of "Hua Xia tuned out of western China".

According to the interpretation of the On Words (《说文解字》), “Beauty means gump. Also from the sheep, from big. In animals, sheep is mainly for the food-meat. Therefore, Beauty and Good are of the same sense" (“美，甘也。从羊，从大。羊在六畜主给瞨也。美与善同意”).

To this, there are three main schools of understanding. The first is from XU Xuan (徐弦) who was a prominent scholar in Song Dynasty, he said, “big sheep is good, so it’s beautiful” (“羊大则美 , 故从大”).

The second opinion from MA Xu-lun (马叙伦), whose statement is that, XU Xuan (徐弦) calls “big sheep is good, so it’s beautiful, also small ears... Beauty from Qian (芉) sound also” (“徐铉谓羊大则美 , 亦附会耳...... 证美从芉得声也).

The third opinion comes from XIAO Bing (萧兵), who insists that, the originated meaning of Beauty is the crown shape or sheep head decoration of the primitive.

This paper argues that, if the connection to that of the "sheep" the totem deriving and witchcraft ritual historically scenarios, such as "big sheep" and "sheep head decoration of the primitive" are both the same connotation and show different sides in the meantime. That is to say, "sheep" is both because of its connected to the clan totem, so "big” people (wizard or the emirates) is the later at the beginning of the "beauty", also because of its "big” to infer for food. Thus, sheep "big”, "food" and beautiful decoration with the primitive gradually in a progress onto the "Beauty". Hence, the boundaries of "beauty" is not a matter of it whether "big” or "decoration" respectively, but does lie in the complex understanding of how is the word "beauty" itself derived from points of different sides.

In our view, "beauty" is a comprehensive knot, an idea of instantaneous symbol in a historical approach. Namely, the early formation of the accumulation of "sheep" taste laid the foundation for "beauty". We might as well think, the first is "great" beauty (sheep), then to form the "artificial decoration" beauty (primitive). There is no doubt that this is due to early humans who felt the natural physiological fast optimum, only on this basis for the spirit of the cultural main body emotion laid a solid base on perceptual to meet the rational foundation. On this basis, the development of "beauty", in fact is developed on the basis of Zi Wei (滋味). Therefore, the "beauty" step by step, from “big sheep” to “sheep of the primitive” (从“羊大为美”到“羊人为美”), by sensory meeting to magic singing and dancing, the word for posterity aesthetics of the Chinese art and culture (resort to perceptual and beyond the perceptual) lay the foundation of etymology. As is known to all, Zi Wei (滋味) as the basis of physical sensation fast optimum, is prior to the rational cognition. Eventually, by Zi Wei (滋味), “Sheep Big” turns to "Beauty Great".

Parker (Dewitt Henry Parker, 1885-1949), an American esthetician pointed out that, feeling is a portal into the aesthetic experience world, and the foundation of the entire structure rely on. Smell, taste, touch, and kinesthetic can play in the people's aesthetic feelings such as the effect that cannot ignore. Psychology experiments also show that if only the smell, taste, touch, and loss of vision, hearing, the object will be a mixed 
feeling repeatedly and not to be understood; if only visual, auditory, however, feeling out other (confirmed), the object will appear in the feelings can understand but appears fuzzy, illusory and difficult to determine whether it is the objective existence.

Due to the richness and complexity of people feeling, the human aesthetic experience is the basis and starting point. This is based on the aesthetic object and the scientific nature of the human physical sense (connection) on psychological again deduces (difference). Aesthetic feeling is visible, physical and chemical structure, physical structure and the organic conjunction between and among social psychological emotion structure. For example, when we appreciate the music “Wave of the Danube” ( 《多瑙河之波》) because of its continuous sliding up and arouse some kind of distinctive visual feeling and dread of movement. Traditional Chinese ancient music of “Departure at the Front Yang Guan” (《阳关三叠》) contains, moreover, lasting appeal, and can arouse much more rich emotional tone, by its unique concise, depressed, keyed to the tune of comprehensive feeling conveying a dramatic effect, thus it had a more fully outside of music, to the situation of poetry and painting, which also made more spreading out on the music. In this sense, Zi Wei (滋味) can also arouse more and deeper aesthetic implication.

\section{New Path From Zi Wei (滋味) to He Xie (Harmony, 和谐)}

Human diet culture originated from the end of drinking blood and keep warm with skin era, which is civilized and preliminary. In the human cultural intelligence to port, the formation of the feeding system and special devices to resettle food utensils are the two necessary conditions. As early as hundreds of thousands years ago, as a result of four monuments (i.e., fire, planting, breeding, and ceramics) had been laid on, the diet culture of the Chinese nation began.

In the pre-Qin period, delicious food not only appeared as core of the diet culture dishes, delicious food, also appeared with its historical records that meet the needs of related cooking, etc., such as, Shang Shu (《尚书》), Zuo Zhuan (《左传》), The Book of Songs ( 《诗经》), The Spring and Autumn Annals (《吕氏春秋》), The Rites (《周 礼》), and Huangdi Neijing ( 《黄帝内经》), which reflected the works of pre-Qin scholars' as well. For example, in The Spring and Autumn Annals ( 《吕氏春秋》), the flavor in the lists from the Warring-States Period to the early years of the Qin Dynasty of the nation-wide food, such as the "beauty of meat” (“肉之美”), “the beauty of fish” (“鱼之美”), “the beauty of food” (“食之美”), “the beauty of rice” (“饭之美”), “the beauty of water” (“水 之美”), “the beauty of fruit” (“果之美”), and “the beauty of harmony” (“和之美”), etc., basicly cover all kinds of delicious diet cultre at that time.

Due to the recognition of delicious Zi Wei (滋味), it gradually appeared to be represented by Confucius as “Color evil, don’t eat. Smelly evil, don't eat. Cooking wrong, don’t eat. Wrong time, don't eat. Cut is not straight, and don’t eat. No sauce, no food” “色恶，不食。具恶，不食。失饪，不食。不时，不食。割不正，不 食。不得其酱, 不食”).

Thus, according to the food taste whether pure or not, Zi Wei (滋味) was even related to the life attitude, it rose to the height of the life philosophy, showing the clue of the Chinese aesthetic culture fashion style evidently. Since then, Mencius (孟子) also made further expounded in theory to this, he said, "the mouth is to the taste, having the same hobby; the ears to the sound, also having the same listening; eyes in color, also having the 
common sense on beauty” (“口之于味也 , 有同耆焉 ; 耳之于声也 , 有同听焉 ; 目之于色也 , 有同美焉”). This puts the public popular taste sensation based on diet culture to some extent of the aesthetic height to be recognized, and even being extended to the enjoyment of human spiritual life.

In fact, Confucius (孔子) himself often took the beauty of the music to match Zi Wei (滋味) as an example. Once he said, “I really do not percept the delicious Zi Wei (滋味) of meat in Qi (齐国) where I was listening to the symphony of Shao (韶乐); and I really just didn’t think that music should achieve such a height” (“在齐闻韶 , 三月不知肉味，曰: ‘不图为乐之至于斯也!’”). This is probably people later by doing basic taste, the key to evaluate the Chinese traditional art.

In my opinion, the reason why Confucius (孔子) lay stress on Zi Wei (滋味), not only because of aesthetic taste does have a physical sensation as the foundation, and it caused by the "pleasure" people beyond the physical sensation of basic content, thus has a continuity, frankly speaking, "music" as a kind of esthetic art evokes such a kind of profound rational significance that exhibits much more meaningful.

The author believes that the following three points need to be called attention:

Firstly, Confucius (孔子) has always been the pursuit of the life of the transcendent, artistry, and also he means what he emphasized is "consistency" of life and artistic feeling, in this case, as the necessity of life, "food" is the best example.

Secondly, as to the spiritual transcendence of "music", forgetting the delicious "meat" is to remind people of pursuing an actively categorically the ideal faith, not too clinging to satisfy their physical senses, and this is consistent with the idea of Confucian governance doctrine, and is associated with Courtesy and Music Civilization (礼乐文明), also with “Poem Education” (诗教) and “Music Education” (乐教) in the same system.

Thirdly, the harmony of "music" is in similarity with the nature of Zi Wei (滋味).

There is historical evidence in Zhou Dynasty that noted in the documentary about cooking for “cutting-cook”(割烹), namely, the process of cutting raw admixture to boil again, is one of the most important dish "soup” (note the word "soup”, is a small "sheep” add water to boil with fire), "soup” is characterized by taste mixed liquid (flavor in it without shape). According to Zuo Zhuan (《左传》) stated in Zhaogong 20th (520 BC, 昭公二十年), obviously, Yan Zi (晏子) argued with Qi leud (齐侯) on Zi Wei (滋味) and “sound” combined closely.

As a result of Zi Wei (滋味) and “music” with "politics”, the relationship between the Chinese diet culture developed in fact is the Chinese Confucian culture philosophy helped it in progress intentionally. Later on, generations of the Chinese diet culture have laid stress on its delicious food, beautiful vessels, beautiful environment and, appeal for "aesthetic" is inevitable. Mencius (孟子) said, "feed will be full, and then seek beauty” (“故食必常饱, 然后求美”) which is not only the elementary factors of historical materialism, and a more intrinsic to the realm of life and the pursuit of consciousness. Zi Wei (滋味) and He Xie ( Harmony, 和谐) to the Pin Wei (品味, 品位) not only is leisurely and comfortable life, it is as much of a kind of Confucius (孔 子) saying which is the so-called “I see eye to eye with what Zeng Dian’s opinion” (“吾与点也”), an aesthetic realm. It is also coordinated with JIN Sheng-tan (金圣叹) that more than 20s “not as well so happy” (“不亦快哉”) interlinked in spirit.

By the same token, it is with Chinese traditional aesthetic category of Yi Wei (意味), Yun Wei (韵味), Qu Wei (趣味), Wan Wei (玩味), Ti Wei (体味), Xing Wei (兴味), Pin Wei (品味), Yu Wei (余味), and a series of 
categories are of the same parent that speak of Zi Wei (滋味) and beyond Zi Wei (滋味) is an outward-rhyme, outside the flavor of the implied.

A Harvard professor, Mr. ZHANG Guang-zhi (张光直, 1931-2001), once asked, "Is the essence of ancient Chinese civilization through the ancient Chinese own use or enjoy a banquet meal and expressed in the form of rules?” The answer is: Yes. If there is no traditional Chinese concept of Zi Wei (滋味), the "Man-Han Banquet" (满汉全席) and the Chinese diet culture with a series of cuisines wouldn’t have been so amazing.

Furthermore, not only as a "diet" in the secular ethics and measure, it is to entertain the best means to the deceased (such as a memorial offering). As stated in the analects of Lun Yu (《论语》), "What a wonder, Yan Hui ! A bowl of rice, a ladle of drinking water, living in poverty alley, everyone is worrying about you, while Yan Hui revels himself continuously” (“贤哉回也! 一箪食, 一漂饮 , 在陃巷, 人不堪其忧, 回也不改其乐”). The poem in the “Chu CI· Evocation for Spirit” (《楚辞・招魂》), for example, with exquisite dishes calls dead creatures back to life and enjoy the flavors.

Diet is important, not only lies in what ZHANG Ying's (张英) saying, “to preserve one's health, to be happy on it” (“食以养生, 以畅为福”), the key also lies in “what humans' valuable is food, while the food is precious for time” (“人所贵重者食也, 食所贵重者时也”). As to the reason why, we can find that wine dinner is the method to rely on time, it can “release the melancholy, only in Dukang” (CAO Cao, 曹操, “何以解忧 , 惟有杜康”) by “getting drunk”. "Diet” (here metaphors for time) and eating behavior have become the Chinese clan, sacred ceremony, used for ancestor worship, and used for the posterity to enlighten education, at the same time also to the emperor to exhort, “to ease the heart to achieve his majestic ambitious targets” (“以平其心，成 其政也”), and its principle is lying in “Five-flavor enrich people’s spirit, five-color pure their hearts, and five-sound outstand people’s virtue” (“五味实气，五色精心，五声昭德”).

As a result, music and dance accompaniment is indispensable to the large feast activities, for example, in the period of Tang Dynasty, “Yan Music” (燕乐) is actually "Banquet Music”. With “diet”, diners keep alive peacefully and harmoniously (“养生”) and “raise” the purpose of “cultivation of the character” (“养性”). This “politics into reproduction, is the ecstasy of music” (“政成生殖, 乐之至也”), and this is also a path to the internal logic orbit of the “harmony of taste” (“味和”), “harmony of sounds” (“声和”), “harmony of spirits” (“气 和”), “harmony of minds” (“心和”), “harmony of politics” (“政和”), incorporated in the monarchy rational track, and eventually with the notion of "writing loading doctrine” (“文以载道”) to maintain the consistency of the system.

\section{Aesthetic Pursuit From Zi Wei (滋味) to Dan (淡)}

In the period of the Spring-Autumn and Warring-States period, it was also an era of "Collapse of the Etiquette System” (“礼崩乐坏”), but also kept up with the change of the times and aesthetic taste changes. Follow this train of thought, the author try to comb through the relationship between Zi Wei (滋味) and Dan (淡) to collect the new aesthetic trajectory.

As is known to all, the Chinese nation since ancient times is known as the "Civilized Nations", "the State of Etiquette and Music” (“礼仪之邦”), because “the ritual” and “music” are the two pillars of the Chinese culture, and the two pillars into Confucianism’s “Ritual System” (礼教) and “Music Education” (乐教) being to come, 
which generalized the "music" (including "poem”) that originated in the early Chinese diet culture.

Here are the records as proof from The Rites (《礼记・礼运》), “The beginning of the so-called courtesy, started in the diet” (“夫礼之初，始诸饮食”). “The Ritual” is the result of the Chinese diet culture is no doubt, the problem is that the ancients are often on the diet, but in order not to forget their ancestors on teaching their cultivation on farms, the so-called “on sacrifice, the gentleman cannot ungrateful to their ancestors” (“礼 , 饮食 必祭, 示有所先”). Diet before the ritual activities held constant, and the formation of a set of fixed and perfecting instrument gauge, then developed into "the ritual” later. People also acted as a daily feeder phenomena and ritual vessels. Therefore it was said, "the ritual” from the moment of production, with ancestors' diet activities which were closely linked together.

According to the interpretation of On Words (《说文解字》), Wei (味) glyph radical from “kou” (口), and pronunced as Wei (末), means taste (“味, 从口 , 未声” , 意为 “滋味”). Its original meaning is “taste, the taste in June” (“味也，六月滋味也”). In the Book of History·Rhythm (《史记·律书》) records, Wei (末), means “all things done, has the flavor” (“未者, 言万物皆成, 有滋味也”). Thus, Wei (未) and Wei (味) share the same pronunciation.

Due to the formation of the Wei (味) as the principle of "beauty”, Wei (味) and the culture are maturing, “Five-flavors” (五味) along with the “Five-colors” (五色), “Five-sounds” (五声) link as an increasingly category of human life. As we mentioned above, “Ritual System” (礼教) and “Music Education” (乐教) come along with the Chinese diet culture, make complements each other.

However, because of the “collapse of the Etiquette System” (礼崩乐坏) on one hand, due to too much attention to the “Five-flavors” (五味) along with the “Five-colors” (五色), “Five-sounds” (五声) on the other hand, thus unconsciously goes to the opposite of "Ritual System” (礼教) and “Music Education” (乐教). Finally it developed from Wei (味) but has its regularity of the emergence of the aesthetic category—Dan (淡)—which means a kind of light flavor. The first-of-its-kind representative is Lao Tzu (老子), as he stated in Dao De Jing (《道德经》), “Five-colors” (五色), make human blind, “Five-sounds” (五声) make human deaf, “Five-flavors” (五味) make human non-taste, along with the galloping-hunting makes their hearts crazy, and rare goods make their activities hindering. Therefore, "the saints for real and not by appearance dazzle, so do the choice” (“五色, 令人目盲; 五音, 令人耳聋; 五味, 令人口爽; 驰骋畋猎, 令人心发狂; 难得之货, 令人行妨。是以 圣人为腹不为目，故去彼取此”).

Accordingly, Lao Tzu (老子) put forward Dan (淡) to limit the expansion of aesthetic category. He increased it to a metaphysical height to make it being recognized, “the exposure of the Dao (道) appears insipidity, insufficient to see, fuzzy to listen” (“道之出口, 淡乎其无味, 视之不足见, 听之不足闻”).

We believe that Wu Wei (无味, tasteless) is also a kind of Wei (味, taste), and it is a huge and ultimate taste as well, just as a kind of "great music feeling soundless” (大音希声) which is penetrating into human life style on a very large scale of taste realm. Here "taste" is neither referred to somgthing toeat, neither to understand the taste of "listening to people how they are talking (words)", it is actually a kind of Dao (道) of another necessity for a description of the way. This Wu Wei (无味, tasteless) is a kind of classical taste, a kind of aesthetic interest that link to Ping Dan (平淡, flat taste). It is just a kind of “taste” as Wang Bi (王㢶弓) discussed that “For light flavor is the right taste” (“以恬淡为味”), and what Lao Tzu (老子) regarded it as “Interest is better to light, too much is not beautiful” (“恬淡为上, 胜而不美”). 
Since then, it is not difficult to find a bunch of serene interest of literati, the most representatives are TAO Qian (陶潜) who was in Jin Dynasty, WANG Wei (王维) in Tang Dynasty, and SIKONG Tu (司空图), SU Shi (苏轼), MEI Yao-chen (梅尧臣) and a large number of scholars and artists in Song Dynasty.

Therefore, starting from the concept of Wei (味, taste) gradually derived He Xie (Harmony, 和谐) which has the unique taste of artistic style and aesthetic categories, namely, Ping Dan (平淡, flat taste), one of the aesthetic criterion of evaluation of arts.

\section{Yi Jing: The Aesthetic Pursuit of the Evaluation Based on Zi Wei（滋味）}

Zi Wei (滋味) clearly put forward as an aesthetic category, can be found in ZHONG Rong's (钟嵘) works in the earliest Ji Liang era (齐梁时代). In his preface to works, ZHONG Rong (钟嵘) explicitly stated, “to achieve the highest degree, touching people's taste of aesthetic into their hearts, it is the ultimate purpose of poetry” (“使 味之者无极, 闻之者动心, 是诗之至也”).

That is, ZHONG Rong (钟嵘) in the poetics on Zi Wei (滋味) also appears in his contemporaries, as Ji kang (嵇康) stated in the Poems On Qin ( 《琴赋》) that “flavor is excessive, the voice of quietly elegant is everlasting” (“滋味有弲，而此不倦”). It is such an interesting thing that, a self-described is defined as “being beyond the mainstream ideology and pursuit of nature” (“越名教而任自然”), JI kang’s (嵇康) point of view on Zi Wei (滋 味) is derived from the classical work On Music (《乐记》), frankly, “in the ancestral temple and in the ceremony, the music lingering for days; and the sacrificial rites, smell advocating lasting” (“清庙之瑟, 朱弦而疏越, 一倡 而三叹, 有遗音者矣”).

In my point of view, this passage is clearly influenced by Lao Tzu (老子) on Wu Wei (无味, tasteless). Here, what readers may ask is: As a poet and the prominent critic, why on earth did ZHONG Rong (钟嵘) especially select the word Zi Wei (滋味) as his main concern? Take a look at him in the preface to On Poem (《诗 品》) which is very prominent, Qi (气) as the spirit of the animal being so touching, it can sway people’s temperament, to resort to singing and dancing... but what attracted to the Nature, even ghosts and gods, the best weapon is the effect of the poetry (气之动物, 物之感人, 故摇荡性情, 形诸舞咏...... 动天地, 感鬼神, 莫 近于诗).

In addition, there are so much alike statements advocating Tian Dan (恬淡) within On Poem (《诗品》), such as, Selected Poems from Wei Chen Si Wang Zhi (《诗品上·魏陈思王植诗》), Selected Poems from Jin Huang Men Si Lang Zhang Xie (《诗品上·晋黄门郎张协诗》), Selected Poems from Jin ZHONG San Ji Kang (《诗 品中•晋中散稽康诗》), Selected Poems from Jin Hong Long Tai Shou Guo Pu (《诗品中•晋弘农太守郭璞诗》), Selected Poems from Song Zheng Shi Tao Qian (《诗品中•宋征士陶潜诗》), Selected Poems from Song Guang Lu Da Fu Yan Yan-zhi (《诗品中•宋光禄大夫颜延之诗》), Selected Poems from Jin Biao Qi Wang Ji (《诗品 下•晋骠骑王济》), etc..

ZHONG Rong (钟嵘), we think that the objects of his arguments are poets and poetic works, he actually wants to sort out the art of poems and articles to unify people's tasting measurement, and to establish the composition and evaluation standard of the poetry. By using the poetic history, many people in times of ZHONG Rong (钟嵘) carefully checking work, he finally found an appropriate aesthetic categories: Zi Wei (滋味).

In Ming Dynasty scholar HU Ying-lin (胡应麟) once pointed out the reasons why ZHONG Rong (钟嵘) 
“through in tracing the origin” (“历溯渊源”), its purpose is to “hit at that time and later generations chase the disadvantages of the new trend” (“能中当时、后世好新之弊”).

To this, we believe that not only that, but he is in order to achieve “deep from the Liu Yi (六艺, Six Arts) for studying and differentiating the schools... to grasp sutras still, and into pure peek into heaven and earth, the body of the ancients” (“深从六艺溯流别也......则可以探源经籍，而进窥天地之纯，古人之体矣”). His ultimate goal is to find the origination from the historical source of primitive simplicity taste—Zi Wei (滋味).

People may ask: Why ZHONG Rong (钟嵘) doesn't choose other kinds of art, and just choose the poem to describe the art of aesthetic interest? He believed that the answer possibly is: Poem (诗) and Qi (气) is so much alike and related. "Poem” (诗) is not only a piece of “poem”, it also connects with "music” and "dance”, it peculiarly arouses "emotion", that is his choice when the nation-wide writing poems about poetry held in succession the era of fashion, also the traditional Chinese is a poetry nation are closely related.

The crux of the problem is that Poem (诗) and Zi Wei (滋味) have much alike properties, this is the reason why he used to talk about Poem (诗) as that of the origins of art.

First of all, Poem (诗) and Zi Wei (滋味) have much similarities, for example, sensibility and experience, and by Poem (诗), one can use Qi (气) to direct appeal to people's feeling, perception, synesthesia, enlightenment directly, etc.

In the second place, Poem (诗) is much alike the connotation as Zi Wei (滋味) on ambiguity, also has the characteristics of strong subjectivity, and has a distinct personality characteristics. On this, there is an old Chinese saying, "the interpretation of the poem, no unified standard” (“诗无达诂”) can happen just as it happened in that of western quotation, “when it comes to interest, free debate” (“谈到趣味无争辩”).

Futher more, Poem (诗) and Zi Wei (滋味) also tend to be a highly pursuiting of Pin Wei (品味) and as much a kind of higher degree of the interest, which is undoubtedly a glimpse of the Wu Wei (无味, tasteless), a non-poetry in the poetry of Zi Wei (滋味). Now that “the most excellent poet is unnecessary to write poetry” (“最 高超之诗人不作诗”), as Zong Bai-hua stated, is impossible, only by gradually come close to the Zi Wei (滋味) of light Zi Wei (滋味) to do, so it is the reason why ZHONG Rong (钟嵘) put forward the tenet of Zi Wei (滋味) as a benchmarking. Anyhow, what on earth does ZHONG Rong (钟嵘) put forward Zi Wei (滋味) for the purpose? It lies in the pursuit of the ideal of art aesthetic scale, and looking forward to purifying and promoting the general public the aesthetic art appreciation level with unity.

As a kind of self-conscious aesthetic pursuit, Zi Wei (滋味) at the same time is also found in other types of arts. For example, according to the Selected Works of Su Dong-po Volume 23, to Huang Zi-si Poetry (《苏东坡 集》前集卷二十三《书黄子思诗集后》) recorded, “I have been talking about calligraphy. My view is that ZHONG Yao, WANG Xi-zhi's calligraphy works, by natural and unrestrained and infinite. Its advantages far exceed the calligraphy stroke line outside... While, when it comes to poetry, situation is the same. But WEI Ying-wu himself, LIU Zong-yuan set thick ink in concise, ancient style, on an infinite mean in mild, it is not others who can achieve” (“予尝论书，以为钟、王之迹，萧散简远，妙在笔画之外。至于诗亦然......独韦 应物、柳宗元发纤秾于简古、寄至味于澹泊，非余子所及也”).

The expression of Zhi Wei (至味, ultimate taste) is a natural taste pursue of significant, aftertaste and not deliberately, transferred to some "the way of heaven and earth” (“天地之道”) so that the pursuit of the real art will return to the root of Dao (道). 
If we carefully explore the Model on Calligraphy (《书楷》), written by TANG Lin-chu (汤临初), and compare it with Zhuang Zi (庄子), they will marvel at the point of the both of them to achieve such a high degree of conjunction, it is definitely not a coincidence.

TANG Lin-chu (汤临初) once stated, “calligraphy pays more attention in the connotation rather than skill, quietly elegant is gorgeous, appeal to the natural and not intentional” (“书贵质不贵工 , 贵淡不贵艳 , 贵自然 不贵作意”).

While, as those stated in Zhuang Zi· Ke Yi (《庄子·刻意》), “if the Zhi Wei (至味, ultimate taste) being set, all things are followed by beauty. This is the way of heaven and earth, the virtue of heaven and earth... empty, Tian Dan (恬淡) and calm, only suitable for the virtue of heaven and earth” (“淡然无极，而众美从之，此天地 之道，圣人之德也......虚无恬淡，乃合天德”).

Thus, Zi Wei (滋味) of pure, natural, simple, ancient, etc., which is Sheng (生, raw) beyond the skill of the work, from here, people get into the ideal realm, this also is the highest state of Chinese literati painting.

Painter YUN Nan-tian (恽南田) once said, “pen and ink the most concise, the authors intention most often and most subtle. Because of the author, using his Qi (气) in ordinary people often ignore the place, therefore, would be particularly careful understanding” (“笔墨简洁处, 用意最微, 运其神气于人所不见之地, 尤为惨 淡”). He set NI Yun-lin (倪云林), another painter lived in Yuan Dynasty, as an example to illustrate, “Yunlin is absolutely flux with Nan Gong—this is the true quietly elegant silence, if you draw a line, vulgar!” (“云林通平 南宫一一此真寂寞之境, 再着一点便俗!”).

By the same token, scholar SHEN Ye (沈野) lived in the Ming Dynasty also introduced the aesthetic category of Tian Dan (恬淡) on Zhuan Ke (管刻, seal cutting). He said, “Zhuan Ke (管刻, seal cutting) also has style, silently, marginal infinite, this is the seal of the Zen... taste the tasteless, but it will be a special good taste and unexpectedly appearance; hearing no sound, but there's a metaphysical sound burst out of Heaven and Earth, this seal is poetic” “印章亦有禅理, 不著声色, 寂然渊然, 不可涯涘, 此印章之有禅理也...... 尝之无味, 至味出焉, 听之无音, 元音出焉, 此印章之有诗者焉”).

Artist LI Ri-hua (李日华) has well put it, “the painting must be in the slim for scenic spots, if there is no empty spirit state of mind and open and clear mind, he (or she) is just unable to make it. This is the so-called Qi Yun (气韵), must be experienced of Qi (气) flowing, recycling experience the $X u$ Dan (虚淡, light taste) which is much significant in relatively weak form!” (“绘事必以微茫惨淡为妙境，非灵阔澈者不易证入，所谓气韵 必在生知, 正此虚淡中含意多耳!”).

Therefore, Dan (淡) is not only a kind of empty and lonely taste, but the scenic spots of Qi (气) flowing. Dan (淡) is a kind of moving in the static, it evokes people’s original simplicity awareness, a rational program stressed to the lowest, from the moment of degrees, from its nature of Zi Wei (滋味) after the flowing of Qi (气) and into the outside world. Dan (淡) is actually the one activity, the unity of purpose and means, by means of this form like that it finds simplicity and flowing of Qi (气), forming Qi Yun (气韵), expressed the highest state of the art, without unified ontology based on Zi Wei (滋味) to the realm of Yi Jing (意境).

It is accustomed to Chinese traditional culture with the theory of art, and vice versa. Therefore, to extract from the aesthetic category is, of course, closely related to how the circumstances of life. The so-called "life condition" is on the perspective of individual life, Zhi Wei (至味, ultimate taste) will be the state of art and life sense of boundless universe, time to pull together, to go to the reality and the transcendence of individual 
existence, to immortality, and then go to the art and the peak of life, and lead to the philosophical implication layer. This is the deepest, most unique works of art, and also the most display creation ability.

Step by step, through $Z i$ Wei (滋味), aesthetic subject by the aesthetic perception, emotional imagination, rational meditation, it reaches deep inside information, beyond language, the text level, social-historical level, outside of infiltrating the implication and taste purport to the connotation of the eternal value of the universe and the life emotional appeal, namely, transcendental integration.

\section{Conclusion}

Above all, by the sense of Zi Wei (滋味), to the culture of Pin Wei (品味), by the pursuit of Dan Wei (淡味), gradually transition to the conscious pursuit of Qi Yun (气韵), and Yi Jing (意境), and it eventually integrates the cultural aesthetic tradition of Chinese arts constituted a clear cultural understanding the aesthetic category series of system, it is undoutedly that, Zi Wei (滋味) in which played an important role in primary.

\section{References}

XU, S. (1963). 《说文解字》(On words). Bejing: Zhonghua Book Company.

XIAO, B. (1981). Aesthetic trivial notes to Cu Ci, Aesthetics. Shanghai: Shanghai Literature \& Arts Press.

LI, Z. H., \& LIU, G. J. (1984). The History of Chinese aesthtics. Beijing: China social science press.

The pre-Qin Historical Neatening Cooking. (1984). Beijing: China Commercial Presss.

LV, D. S. (1986). 《诗品》(Annotations to the poem). Beijing: Peking University Press.

ZHANG, X. C. (1994). The General study on the Literature and history of China. Bejing: Zhonghua Book Company.

The Department of Philosophy of Peking University. (1980). The selected materials of Chinese aesthetics. Beijing: Peking University Press.

ZONG, B. H. (1987). Art realm. Beijing: Peking University Press.

NIU, L. F. (1985). Hints on Chinese ancient. Lanzhou: Gansu People’s Press.

笠原仲二. (1987). The beauty of the ancient Chinese consciousness. Beijing: Peking University Press. 